\title{
Efficient Consumer Response (ECR) Practices as Responsible for the Creation of Knowledge and Sustainable Competitive Advantages in the Grocery Industry
}

\author{
Ignacio Soret, Carmen de Pablos, and Jose Luis Montes \\ ESIC Business School and Rey Juan Carlos University, \\ Madrid, Spain
}

\author{
ignacio.soret@esic.es, carmen.depablos@uric.es, \\ joseluis.montes@uric.es
}

\begin{abstract}
This paper presents a model to measure and to explain knowledge and sustainable competitive advantages generation within the Efficient Consumer Response (ECR) framework. Some specific goals are: a) identification, selection and validation of intellectual capital and of sustainable competitive advantages, b) study of what we name associate concepts: facilitators, implantation drivers and critical success factors, c) develop a validation of a methodology for the measurement model and of the indicators adaptation degree, meeting the demand of related companies and consultants.

Results show that individual improvement, work conditions, management style, learning improvement, education, management by objectives and work environment influence directly the human capital increase. Data mining techniques, generation of manuals of procedures and processes, and continuous improvement can be evidenced for a structural capital increase. Increase of relational capital is in direct relationship with the creation and improving of standard procedures for clients, their satisfaction, management by categories, and loyalty programs. To conclude, the implementation of ECR practices generates and increases the intellectual capital, or knowledge, in the organizations by positively promoting the generation of sustainable competitive advantages.
\end{abstract}

Key words: efficient consumer response, ECR, cooperation strategies, best practices, intellectual capital, sustainable competitive advantages, structural equations model

\section{Introduction}

Material published as part of this publication, either on-line or in print, is copyrighted by the Informing Science Institute. Permission to make digital or paper copy of part or all of these works for personal or classroom use is granted without fee provided that the copies are not made or distributed for profit or commercial advantage AND that copies 1) bear this notice in full and 2) give the full citation on the first page. It is permissible to abstract these works so long as credit is given. To copy in all other cases or to republish or to post on a server or to redistribute to lists requires specific permission and payment of a fee. Contact Publisher@InformingScience.org to request redistribution permission.
The Efficient Consumer Response initiatives (ECR) have their origin in the United States, after the Annual Conference of the Food Marketing Institute and previous to a pioneer action coming from Walt Mart, with the main purpose of improving the productivity in the products supply chain from a global perspective. 
Between 1992 and 1993 many consultants started to develop the concept ECR inspired by the production system in Toyota, more concretely in the "just in time" system. After that, in 1996, the $1^{\text {st }}$ ECR Conference in Europe was held. That same year, ten different organisations started the Project ECR-Spain. In 2002, according to the AECOC, ECR-Spain and Accenture Report (2002), more than 26.000 collaboration and communication agreements in ECR practices were established in the areas of demand and supply of this kind of services.

ECR is a strategy in the groceries industry. According to it, suppliers and intermediaries work together in order to produce better results for the final consumer (Kurt Salmon Associates, 1993) and improve the attraction of demand (AECOC, 2005; ECR-Spain, 1998; PROMARCA, 2000). ECR practices are more "collaboration strategies" in the supply chain than a new concept of management. It has to do more with a process of elaboration of "best practices".

We think that the adoption of ECR practices introduces a change in some areas and activities in a firm. Amposen (1991), Nonaka (1995), Ciborra and Andreu (2001) amongst others, link the change and the learning efforts in a firm with the generation and management of knowledge. The results of the MERITUM project in the European Union stress the strategic importance of organisational knowledge for the building of competitive advantages in firms (Ordóñez, 2000).

From Brooking (1996) the measurement of knowledge (intellectual capital) has always been of researchers' interest. We have revisited the most important models for intellectual capital measurement and tried to collect the most interesting approaches for our paper.

To measure the impact of ECR practices in the generation of competitive advantages, we have made use of the ITSGA concept "information technology strategic generic actions" (Andreu, Ricart, \& Valor, 1997). Literature has recently paid attention to this methodology, mainly in order to incorporate into the firm's strategic objectives the experiences coming from other firms and the possibilities that the information and communication technologies offer to achieve competitive advantages (Gil \& Guarch, 2006, Palou, 2006, Rambla, 2006, Soto \& Tapia, 2006).

Figure 1 offers the main concepts included in our model

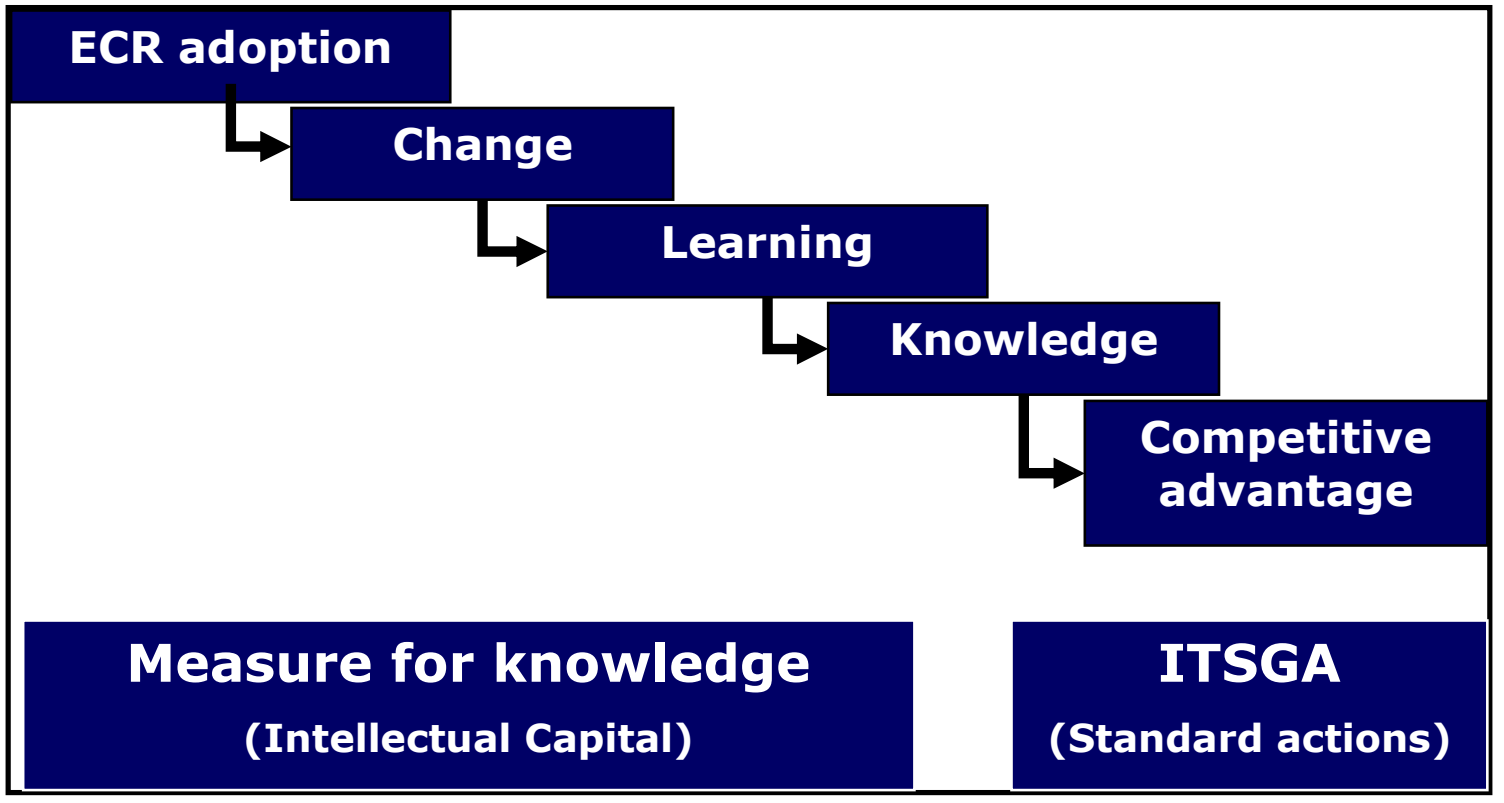

Figure 1. ECR, knowledge and competitive advantages (Soret, 2007) 


\section{ECR: Definition and Elements}

ECR is a joint strategy for providers and distribution channels, dedicated to providing final consumers with the highest value, the best service and the greatest variety of products, by fitting together the needs coming from the firm's supply chain and the customer's needs (AECOC, 2000; PROMARCA, 2000). Solé (2000) refers to ECR as a system and sometimes as a movement. He indicates that it appears in Europe in 1994 in order to eliminate the unnecessary costs in the supply chain and the need of looking for a faster and proper reaction to consumer demands. Ferrer and del Castillo (1996), Stern, Ansary, Curghlan, \& Cruz (1999) and Whipple, Frankel, and Anselmi (1999) have referred to this concept in the same way.

Amongst the main elements considered necessary to the final success in the adoption and implementation of ECR practices we can cite: the relationship between manufacturers and distribution channels (Merrefield, 1992). It requires changes in the firm's structure and in the processes (Shulman, 1993). The ECR practices must not be implemented without considering the creativity in merchandising practices and promotions (Veiders, 1993). ECR implies an investment in information and communication technologies (ICT). The most common ones are: executive information systems (EIS), electronic data interchange (EDI) and radio devices (Buddenbaum, 1994). Effectiveness, flexibility and customer orientation are the principles that must orient the joint actions of all members in the value chain in order to reach the proposed objective (Mejías, García, \& Prado, 2001).

In this work, taking into consideration an orientation towards learning, knowledge and the generation of competitive advantages, we propose the following definition: the initiative ECR is a technique composed by a group of collaboration technologies and procedures that allow the cooperation amongst the stakeholders in a supply chain and that permits the organizational learning and the generation and management of knowledge by promoting a group of distinct capabilities in all the stakeholders that take part, contributing to the establishment of sustainable competitive advantages.

Figure 2 offers the main elements that constitute the ECR initiative.

\begin{tabular}{|l|l|l|}
\hline ECR ELEMENTS & \multicolumn{3}{|l|}{$\begin{array}{l}\text { Efficient replenishment (ER) } \\
\text { Collaboration strategies }\end{array}$} & $\begin{array}{l}\text { Efficient promotions } \\
\text { - }\end{array}$ \\
& & Efficient portfolio \\
& & Efficient offer of new products \\
\hline ECR practices in ER & AFM & Alignment of key files \\
\cline { 2 - 4 } & OER & Orders of entrance and reception \\
\cline { 2 - 4 } & CRP & Continuous replenishment \\
\cline { 2 - 4 } & CPFR & Collaborative planning in replenishment and \\
& & forecast \\
\cline { 2 - 4 } & ASN & Anticipated sales announcement \\
\cline { 2 - 4 } & GXC & Management by categories \\
\cline { 2 - 4 } & C-D & Cross-docking \\
\hline
\end{tabular}




\begin{tabular}{|l|l|l|}
\hline \multirow{5}{*}{ Enabling tools } & EDI & Electronic data interchange \\
\cline { 2 - 3 } & EAN & Identification codes \\
\cline { 2 - 3 } & DW/DM & Data warehouse and Data mining \\
\cline { 2 - 3 } & DPP & Direct product productivity \\
\hline Associate concepts & BPR & Business process redesign \\
\cline { 2 - 3 } & ABC & Activity based costs \\
\cline { 2 - 3 } & KAIZEN & Continuous improvement \\
\cline { 2 - 3 } & MRP/DRP & Material replenishment programs \\
\cline { 2 - 3 } & JIT & Just in time \\
\cline { 2 - 3 } & TRADE MK & Trade marketing \\
\cline { 2 - 3 } & BENCH & Benchmarking \\
\cline { 2 - 3 } & OUTSOURCING & Outsourcing \\
\hline
\end{tabular}

Figure 2. ECR elements for the study

\section{The Model}

This paper has as its main objective the proposal of a model for measuring the knowledge and the generation of sustainable competitive advantages in the area of ECR practices.

Amongst the specific objectives, we can stress the following ones:

- Identification, selection and validation of indicators for intellectual capital and sustainable competitive advantages.

- The study of what we have called "associate concepts". The study of facilitators and promoters for the implementation of ECR practices and critical success factors.

- The proposal of a methodology for validating the proposed model.

- The fitting of the various selected indicators, according to the observed demand, by a group of firms in the chosen industry and consultancy firms.

The model is composed by two main parts: one of knowledge or intellectual capital and the other one composed by sustainable competitive advantages. In order to promote both parts we have revisited the existent models on intellectual capital and the methodology for strategic planning, and the information technology strategic generic actions (ITSGA) that we have mentioned in the introduction.

The most significant models in measuring knowledge in ECR practices are: the Global Scorecard, the derived ECR Scorecard, the five capitals, and the INTELECT models.

We have chosen the INTELECT model for the following reasons:

- It is easy to understand. It is an open, flexible and universal model (Bueno, Rodríguez and Salmador, 2003).

- It is the most extended and operative model in the Spanish market considered by very important firms: BBVA, PriceWaterhouseCoopers, Telefonica R\&D, Zara, etc. 
For measuring the impact of ECR practices in the sustainable competitive advantages we have used the methodology for strategic planning ITSGA (Andreu et al., 1997). It tries to identify "strategic generic actions" that make the achievement of competitive advantages possible. International firms such as Sears, Federal Express or TRW have identified different ITGSA categories for strategic applications such as "transactions by considering customer data", the "development of new products" or "the establishment of new models of collaboration".

In our model, we have considered the three components of intellectual capital: human capital (HC), structural capital (SC) and relational capital (RC). For measuring possible competitive advantages we consider 5 categories of standard actions "product", "customers", "channels", "providers" and of "general interest". We name them ECRSGA, this means strategic generic actions coming from ECR practices.

Each of these 8 blocks ( 3 of IC and 5 of ECRSGA) is divided into elements. Each block has three components; therefore, there are 41 items that constitute the questionnaire that we have used to validate our model.

Each element can have various alternatives that can not be excluded, all together they sum 176 variables measured by "improvement perceptions" in a typical Likert scale.

Figure 3 shows the model for measurement we propose in our analysis.

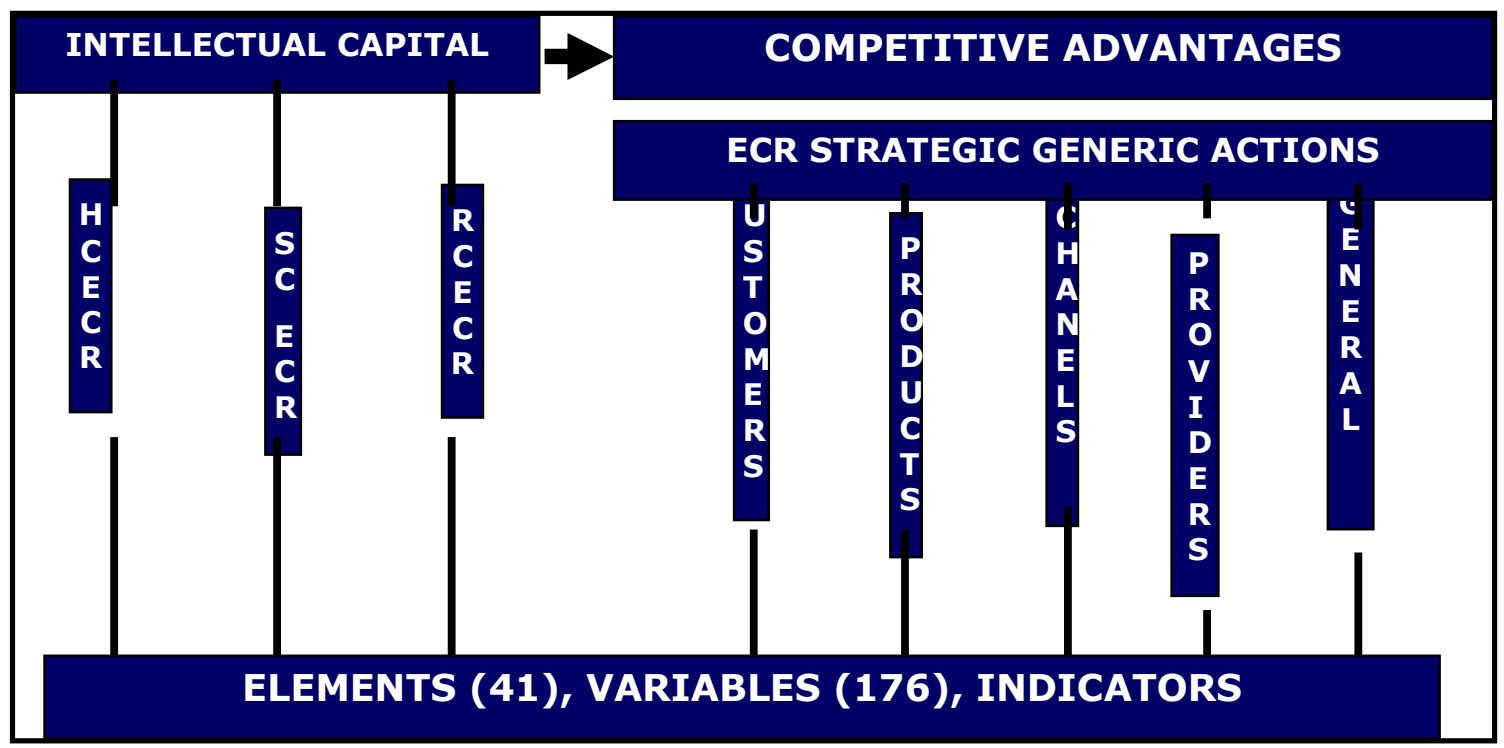

Figure 3. Proposed model for the measurement of IC and CA in the ECR practices (Soret, 2007)

So then by considering the 8 defined blocks, we have established the following hypotheses:

H1: The ECR initiative generates and/or increases the human capital of the firm

H2: The ECR initiative generates and/or increases the structural capital in the firm

H3: The ECR initiative generates and/or increases the relational capital in the firm

H4: The knowledge created by the adoption of ECR generates sustainable competitive advantages related with products

H5: The knowledge created by the adoption of ECR generates sustainable competitive advantages related with customers 
H6: The knowledge created by the adoption of ECR generates sustainable competitive advantages related with distribution channels

H7: The knowledge created by the adoption of ECR generates sustainable competitive advantages related with providers

H8: The knowledge created by the adoption of ECR generates sustainable competitive advantages related with general aspects

The three first hypotheses confirm a general hypothesis: the ECR initiative generates and/or increases the human, the structural and relational capital. That it is to say, the intellectual capital in the organisations.

The rest of the hypotheses confirm another general one: the knowledge generated by the adoption of ECR practices offers sustainable competitive advantages related with various categories.

We will try then, by using a confirmatory analysis, to contrast that the creation or increase of intellectual capital promotes sustainable competitive advantages in the ECR practices.

In the Appendix we present the 176 variables or indexes used. Block I presents indexes for human capital, block II for structural capital, block III for relational capital and from block IV until block VIII we offer indexes for sustainable competitive advantages. Block IX refers to the study of the "associated concepts" as enablers in the implementation.

\section{Work Methodology}

For obtaining the internal and external secondary information, 15 interviews have been conducted with external experts coming from different firms working with ECR practices. From all we have constituted a group of 8 experts.

With this group, we have worked by following a methodology of group dynamics and a further in-depth interview with one of the members. We have achieved a consensus according to the structure for the most adequate model in the industry; finally for the final survey we have established, 8 blocks, 41 elements and 176 variables.

With the help of another group of experts in marketing research, we have designed the questionnaire.

For obtaining the sample framework, we organised a professional meeting in ESIC (Business and Marketing School) in collaboration with LOGICA, the main organisation representing logistic providers in the Spanish market.

We have used some communication media in order to promote the meeting: we offered information in the economic and business press for 4 days; we mailed the information to 2500 different companies and also offered the information in radio and in the web page www.eriete.com

From the meeting we received 65 completed surveys. Afterwards, we received another 27 by conducting personal interviews. All together we got 92 completed surveys. The data have been processed by using SPSS and AMOS. We have realised descriptive and factorial analysis by principal components. The main objective is to obtain a final confirmatory analysis by a system of structural equations containing latent variables and measure errors.

Amongst the participants in the sample we have three groups of business applying ECR practices: logistic operators, firms distributing the products directly to final consumers, and consultants and academics practicing or providing research in ECR practices. These three groups are also the beneficiaries of the results of the research.

Figures 4.1 and 4.2 represent the research process and the main methodology. 


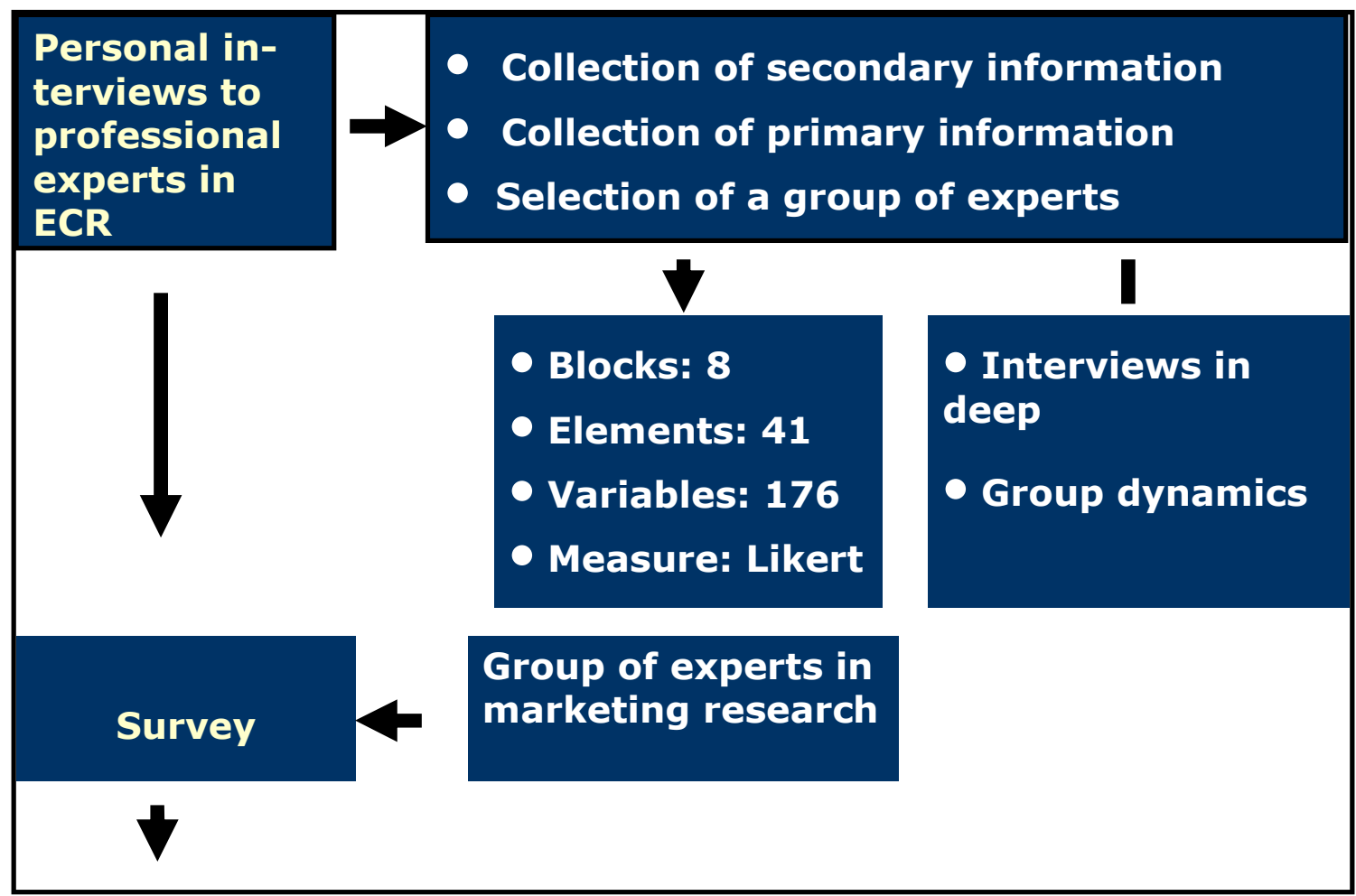

Figure 4.1. Design of the research and methodology

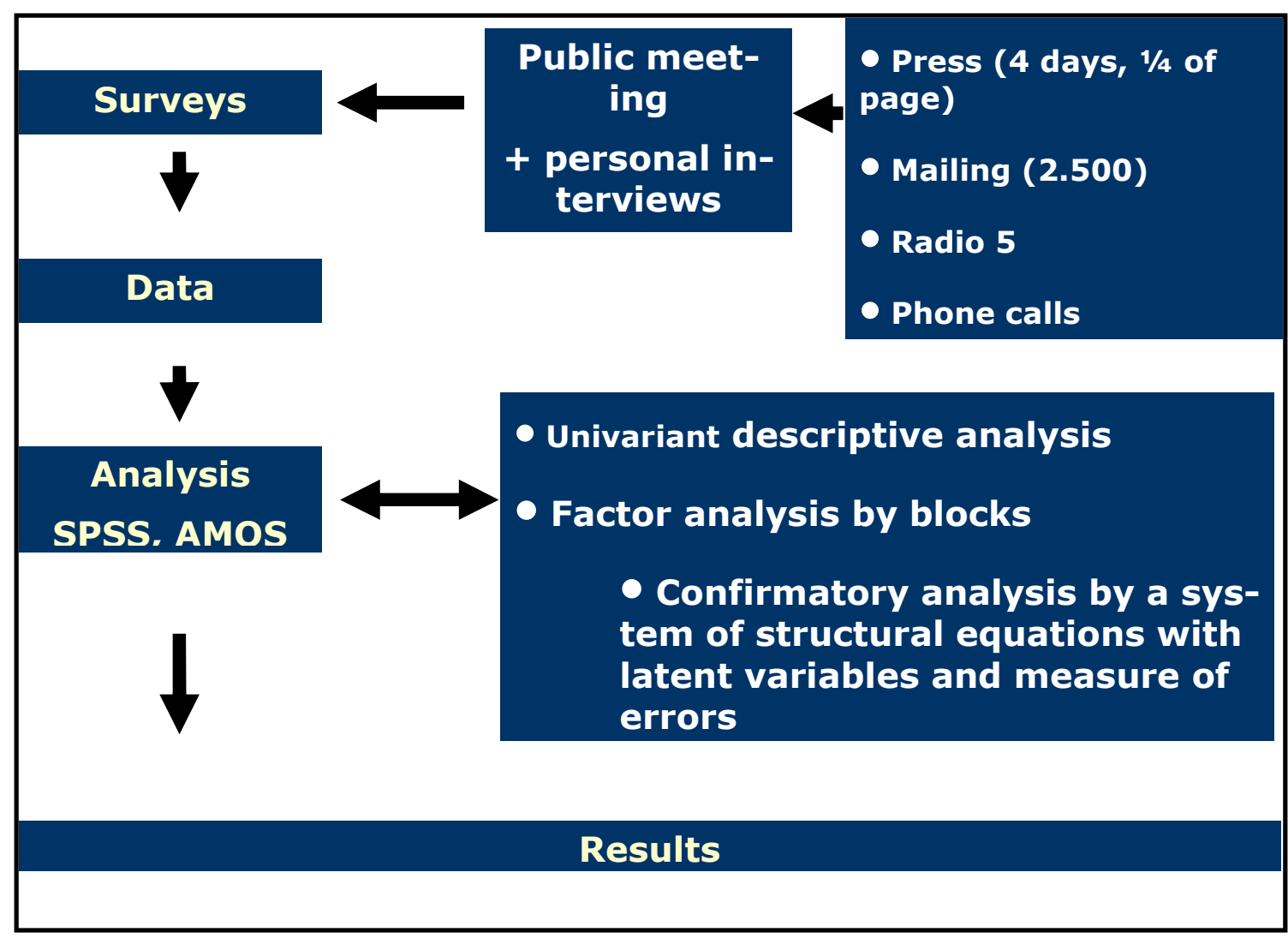

Figure 4.2. Design of the research and methodology 
The factorial analysis offers different dimensions or factors for the different blocks of IC and CA, which will be used as variables in a model of structural equations, MSE, with latent variables and errors in the measure.

The general model of the structural equations systems is a formal mathematical model containing a group of lineal equations that comprise variables that can be directly observed and latent variables that represent associated concepts.

Our model for measuring IC and SCA perfectly fits with the structure of a model of linear structural equations.

The general model is composed by two sub models:

- The structural model that relates the latent variables.

- The model for measure, which relates each latent variable with the variables that measure them (the corresponding indicators).

The latent variables in the structural model are represented by ellipsis and in our case they are $\mathrm{HC}, \mathrm{SC}, \mathrm{RC}$, and SCA

The model establishes that there exits a direct relationship amongst the three capitals with the generation of SCA.

It also establishes a certain relationship amongst the various capitals, although it has been considered a model with direct non reciprocal joint relationships for modelling and identification purposes.

Besides and as a distinct characteristic desirable in the model, the measure errors are explicitly included for each variable in the process of estimation. In Figures 5 and 6 the two cited sub models are offered.

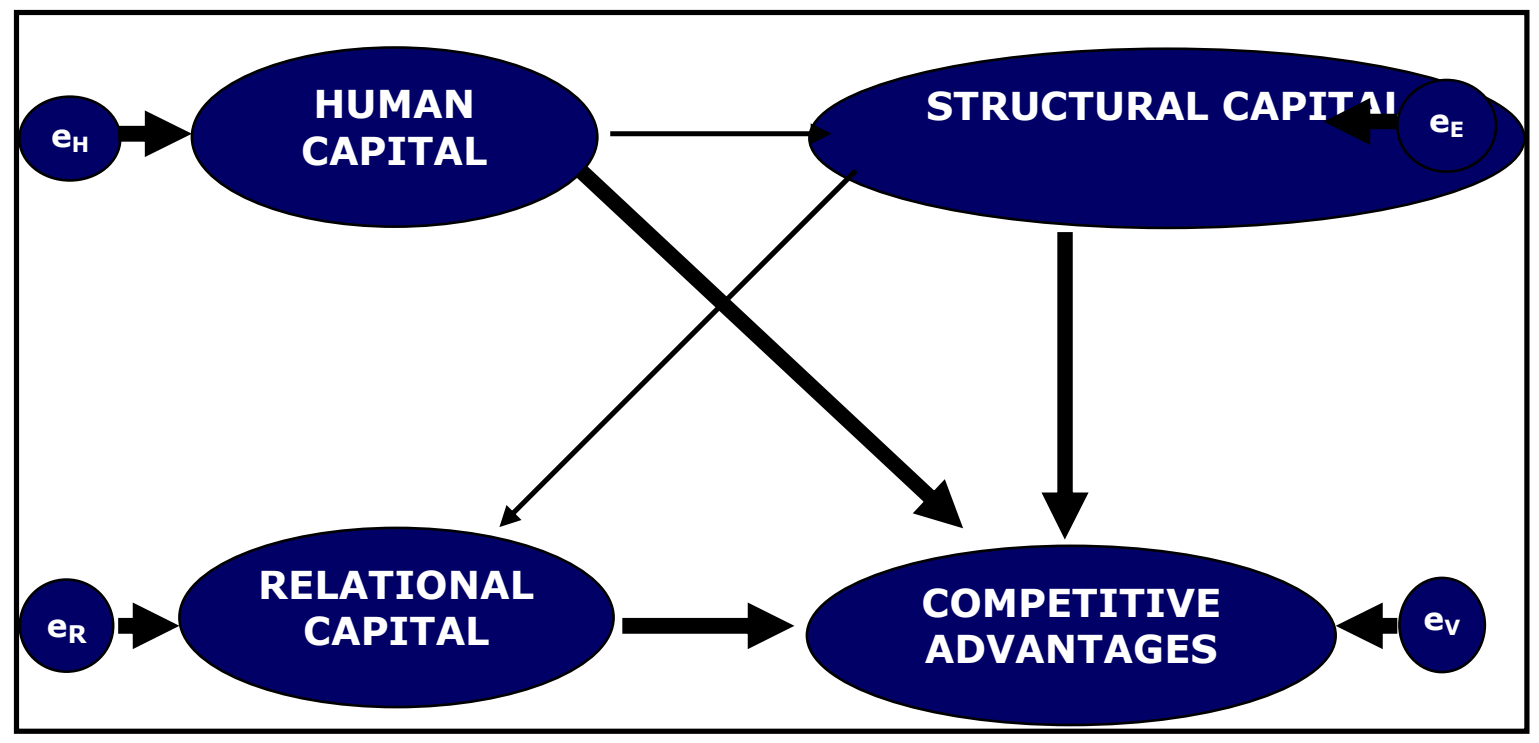

Figure 5. Structural equations model. Structural sub-model 


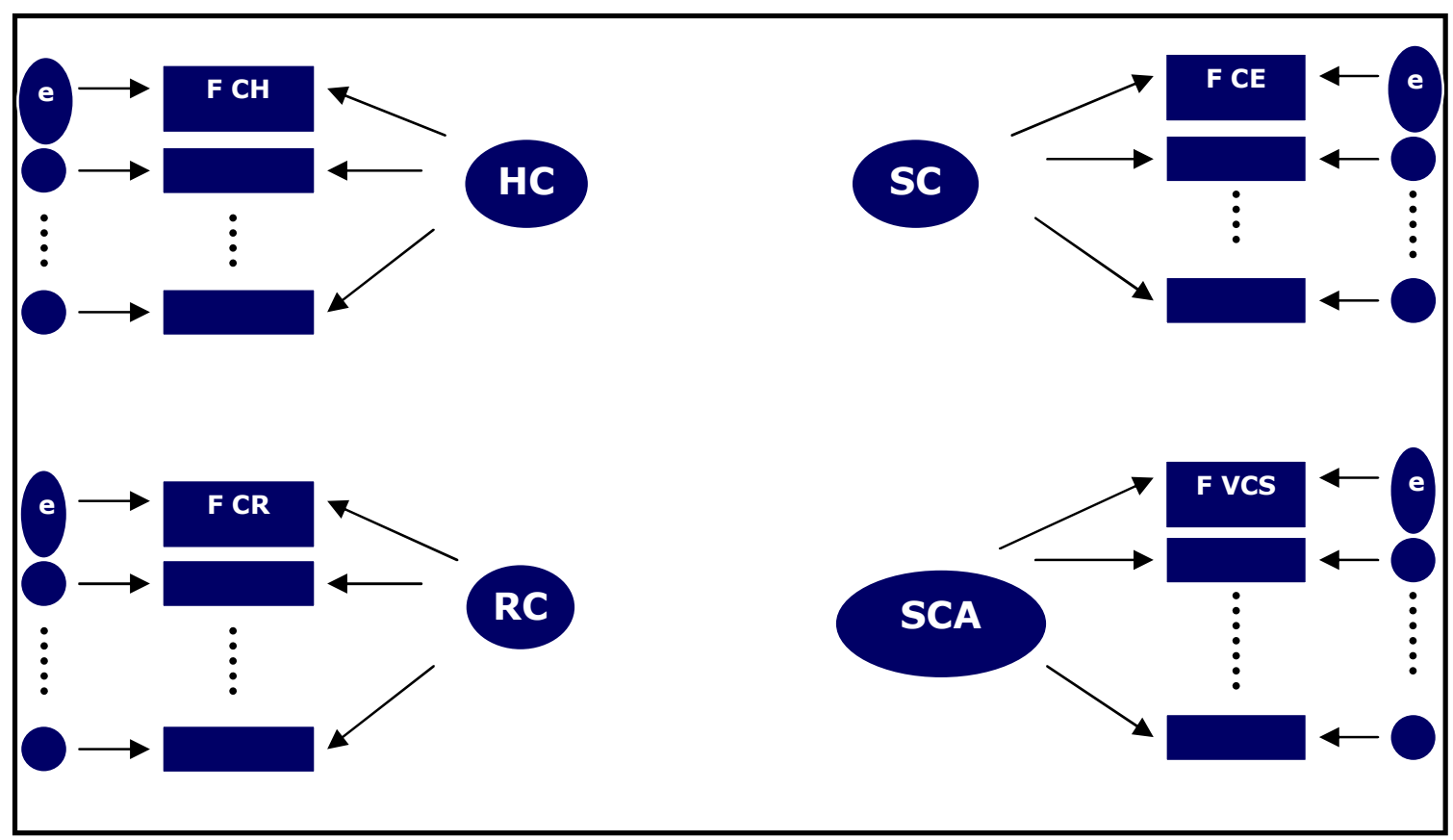

Figure 6. Structural equation models. Sub models of measure

The measurement model relates each latent variable with the correspondent factors (variables used to measure them), by assuming that there exists a causal structure amongst the latent variables. The same way as in the previous structural model, the errors of measurement are included for the whole variable in the estimation process.

The general model is defined (Jöreskorg, 1993) by a system of lineal structural equations with the following matrix representation,

$$
\eta=\alpha+\mathrm{B} \eta+\Gamma \xi+\zeta
$$

where $\eta(\mathrm{m} \times 1)$ and $\xi(\mathrm{n} \times 1)$ are random vectors of, respectively, dependent and independent variables, $\alpha$ is a vector ( $\mathrm{mx} 1)$ represented by the intersections with the axis, $\mathrm{B}(\mathrm{m} \times \mathrm{m})$ is the matrix of coefficients of the endogenous latent variables representing the effects of other variables $\eta$ in other variables $\eta, \Gamma(\mathrm{mx} \mathrm{n})$ is the matrix of coefficients of the exogenous latent variables, representing the direct effects of the variables $\xi$ in the variables $\eta, \mathrm{y} \zeta$ is a vector (m $\mathrm{x} 1)$ that indicates the degree of random effects in the equation. We assume $E(\eta)=0, E(\xi)=0, E(\zeta)=0$.

The observed variables (that we can measure) are represented by the vectors $y$ ( $\mathrm{p} x 1$ ), where $\mathrm{p}$ is the number of indexes of $\xi$, and $x$ ( $\mathrm{q} \times 1$ ), being $\mathrm{q}$ the number of indicators of $\eta$, that are related with the latent variables by equations

$$
y=\tau_{y}+\Lambda_{y} \eta+\varepsilon
$$

and

$$
x=\tau_{x}+\Lambda_{x} \xi+\delta
$$

Being $\varepsilon \quad(\mathrm{p} \times 1)$ and $\delta$ (q x 1$)$ the vectors in terms of errors. It is assumed that $\varepsilon$ is non correlated with $\eta, \xi$ y $\delta$; and that $\delta$ is not correlated with $\eta, \xi$ and $\varepsilon . \Lambda_{y}(\mathrm{p} \mathrm{x} \mathrm{m})$ and $\Lambda_{x}$ (q x n) 
are matrix containing the structural coefficients $\lambda_{i j}$, that relate the latent and measured variables (the observed ones), and $\tau_{y}$ ( $\left.\mathrm{p} \times 1\right)$ and $\tau_{x}$ (q x 1) are the vectors of the terms of constant intersections.

In other words:

$$
\begin{aligned}
& {\left[\begin{array}{c}
\eta_{1} \\
\cdot \\
\cdot \\
\cdot \\
\eta_{m}
\end{array}\right]=\left[\begin{array}{ccccc}
0 & & & & \\
& 0 & & & \\
& & 0 & & \\
& & & 0 & \\
& & & & 0
\end{array}\right]\left[\begin{array}{c}
\eta_{1} \\
\cdot \\
\cdot \\
\cdot \\
\eta_{m}
\end{array}\right]+\left[\begin{array}{llll}
\cdot & \cdot & \cdot \\
\cdot & & & \\
\cdot & & \\
\cdot & & & \\
\cdot \\
\cdot \\
\xi_{n}
\end{array}\right]+\left[\begin{array}{c}
\xi_{1} \\
\cdot \\
\cdot \\
\zeta_{m}
\end{array}\right]}
\end{aligned}
$$

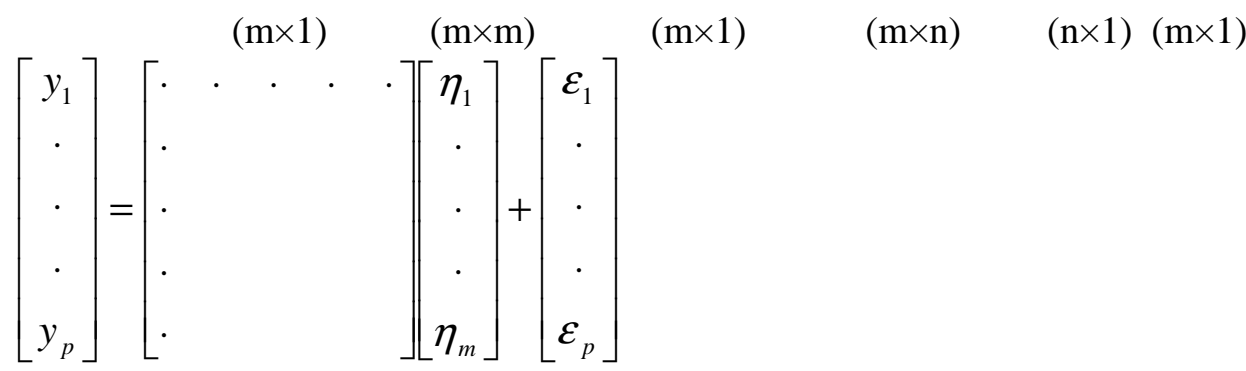

$$
\begin{aligned}
& (\mathrm{p} \times 1) \quad(\mathrm{p} \times \mathrm{m}) \quad(\mathrm{m} \times 1)(\mathrm{p} \times 1)
\end{aligned}
$$

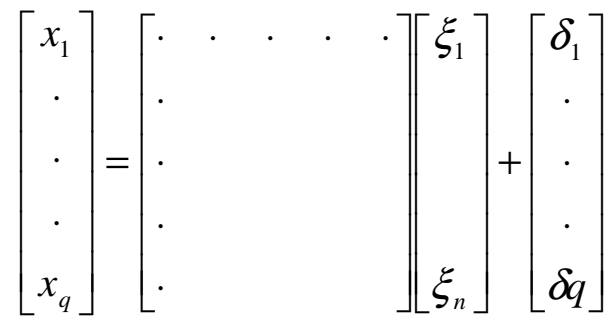

$$
\begin{aligned}
& (\mathrm{q} \times 1) \quad(\mathrm{q} \times \mathrm{n}) \quad(\mathrm{n} \times 1) \quad(\mathrm{q} \times 1)
\end{aligned}
$$

The main hypothesis of the structural equation system is $\sum=\sum(\theta)$, where $\sum$ is the covariance matrix of the population, and $\sum(\theta)$ is the covariance matrix in the model, written as a function of a vector with different parameters $\theta$. The estimations for the parameters are obtained by minimising a function of adjustment:

$$
F(\theta)=F(S, \hat{\Sigma}(\theta))
$$

Once that the parameters in the model have been estimated, the covariance matrix is compared with the covariance matrix of the data and, in case the difference between both matrixes is statistically acceptable, the structural equation model proposed is recognised as a plausible explanation of the reality.

For obtaining more detailed information to estimate in a more precise way of parameters, we realise a Bayesian multiple imputation, 10 complete groups of data have been created. The sample 
was generated by the Markov chain Monte Carlo method, MCMC, by employing a diffuse distribution as a priori distribution. This way, we were able to obtain a sample of 900 data, enough for the estimation.

\section{Results}

In the sample used we have been able to identify three groups of segments containing some common characteristics each one of them. We name them:

C-RD: consultants and researchers

P-D: producers and distributors

LO: Logistic operators

The first segment C-RD shows an academic point of view that offers the opportunity of knowing a high number of cases of study in the industry of mass consumption products.

The segment P-D offers practices where both collaborate a lot, in fact they must collaborate so that the ECR strategies offer final success. So we consider of importance to integrate both from a common point of view in the same sample segment.

The segment LO is the largest segment of responses in our questionnaire. There are two main reasons for this. In the first place, we have collaborated with the main organisation for logistic operators in Spain, LOGICA. In the second place, we have noticed a growing interest of these firms in the last years. We have considered of interest the great participation of these firms in this research paper. They know quite well how the main activities in the logistic area work, activities that they precisely offer as a service catalogue for their customers, manufacturers and distribution channels.

Figure 7 offers the technical specifications:

\begin{tabular}{|c|c|}
\hline \multicolumn{2}{|l|}{ TECHNICAL FICHE } \\
\hline UNIVERSE & Spanish organisations practising ECR \\
\hline ENVIRONMENT & All the nacional territory \\
\hline $\begin{array}{l}\text { DESIGN OF THE } \\
\text { SURVEY }\end{array}$ & The researchers by using group dymanics and in deep interviews \\
\hline$\overline{\text { SAMPLE }}$ & $\begin{array}{l}92 \text { surveys; multichanel strategy: convocatory in the economic press, } \\
\text { phone, personal interview }\end{array}$ \\
\hline ERROR & $\tilde{z} \pm 3,25 \%(p=q=50)($ minimised by Markov Chain Montecarlo) \\
\hline LEVEL OF TRUST & 95 '5\% (2 sigma) \\
\hline $\begin{array}{l}\text { DESIGN OF THE } \\
\text { SAMPLE }\end{array}$ & Quotes; various surveys in a firm \\
\hline FIELD OF WORK & The researchers \\
\hline TIME & March 2007 \\
\hline SEGMENTATION & C-DP: 10(10'88\%); M-D: 27(29'34\%); LO: 55(59'78\%) \\
\hline
\end{tabular}

Figure 7. Technical specifications 
The variables of study have been grouped in 28 factors: 8 for HC, 4 for SC, 10 for RC and 6 for SCA. Each dimension groups various elements in the obtained factor structure, being its denomination representative of the group of the defined elements. These dimensions or factors will be the used as measure variables or manifest ones in the model of structural linear equations.

For a more precise estimation of the parameters, we carried out a Bayesian multiple imputations, by generating a new sample by means of the Markov Chain Monte Carlo method, with a priori diffuse distribution. This way, we have a sample of 900 data, quite enough number for the estimation.

We have obtained a global acceptable adjustment of the structural equation model. The results for each latent variable with their factors, the regression standardized weights and their correspondent p-values, are presented in Figure 8.

\begin{tabular}{|c|c|}
\hline \multicolumn{2}{|l|}{ HUMAN CAPITAL } \\
\hline & (Estimation, p) \\
\hline Improvement of individual and work conditions & $(0 ’ 654,0 ’ 000)$ \\
\hline Managerial style & $(0 ’ 596,0 ’ 000)$ \\
\hline Learning improvement & $(0 ’ 465,0 ’ 000)$ \\
\hline Education-training & $(0 ’ 415,0 ’ 000)$ \\
\hline Organisational environment & $(0 ’ 158,0 ’ 000)$ \\
\hline Integration of people in the firm & $\left(-0{ }^{\prime} 233,0 ’ 000\right)$ \\
\hline \multicolumn{2}{|l|}{ Promotion, Rewards } \\
\hline \multicolumn{2}{|l|}{ STRUCTURAL CAPITAL } \\
\hline Data mining & $(0 ’ 545,0 ’ 000)$ \\
\hline Procedures manual & $(0 ’ 200,0 ’ 000)$ \\
\hline Improvement of processes & $(0 ’ 065,0 ’ 049)$ \\
\hline Communities of practice and virtual university & $\left(-0{ }^{\prime} 269,0 ’ 000\right)$ \\
\hline \multicolumn{2}{|l|}{ RELATIONAL CAPITAL } \\
\hline & (Estimation, p) \\
\hline Customer standards & $(0 ’ 862,0 ’ 000)$ \\
\hline Satisfacción de clientes, GXC & $\left(0^{\prime} 182,0 ’ 000\right)$ \\
\hline Programas de fidelización & $(0 ’ 100,0 ’ 002)$ \\
\hline CRP, CPFR & $\left(-0{ }^{\prime} 272,0 ’ 000\right)$ \\
\hline ASN & $(-0 ’ 155,0 ’ 000)$ \\
\hline \multicolumn{2}{|l|}{ SUSTAINABLE COMPETITIVE ADVANTAGES } \\
\hline Improve of information to $\mathrm{SC}$ and consumers & $(0 ’ 725,0 ’ 000)$ \\
\hline Improve of communication to $\mathrm{SC}$ & $(0 ’ 224,0 ’ 000)$ \\
\hline Degree of personalisation of the product to providers & $(0 ’ 134,0 ’ 000)$ \\
\hline Information on new products & $\left(-0{ }^{\prime} 214,0 ’ 000\right)$ \\
\hline Innovation and price to final customers & $\left(-0{ }^{\prime} 179,00^{\prime} 000\right)$ \\
\hline
\end{tabular}

Figure 8. Standard weights and p-value 
In relationship with the previous results and with the group of basic hypotheses 1,2 , and 3, that it is to say to those that relate to the adoption of practices in the ECR initiative with the generation or increase of the human, structural and relational capital in the organisations; we have verified in our study that there exists a direct relationship amongst the following variables: individual improvement and work conditions, managerial style, improvement of learning skills, training, the management by objectives and the work environment have a direct impact in the increase of HC.

The increase of SC can be obtained by the adoption of data mining techniques, generation of manuals establishing procedures and continuous process improvement.

The increase of RC is directly related with the creation and/or improvement of the standards for customers, their satisfaction, and the management by categories and the loyalty programmes.

Concerning to the group of basic hypotheses 4 to 7 , that it is to say with firms that relate the increase of intellectual capital with the generation of sustainable competitive advantages (SCA), we have verified that there is a direct relationship amongst the following variables: the improvement of information to the supply chain and to the consumer, the improvement of the communication to the supply chain and the personalisation of the product to providers.

In our study the theoretical hypotheses 1 and 2 have been verified. This means that ECR is a technique for individual and organisational learning, and the creation of knowledge and this generates sustainable competitive advantages for firms and organisations in the area of efficient consumer response, ECR.

Or, in other words, ECR improves the organisational results by the creation of SCA. In Figure 9 we can appreciate the parameters in the model for structural equations, and in Figure 10, the results containing the expression of the standard coefficient for regression, the standard error, the critical reason and the value of probability or the significance level.

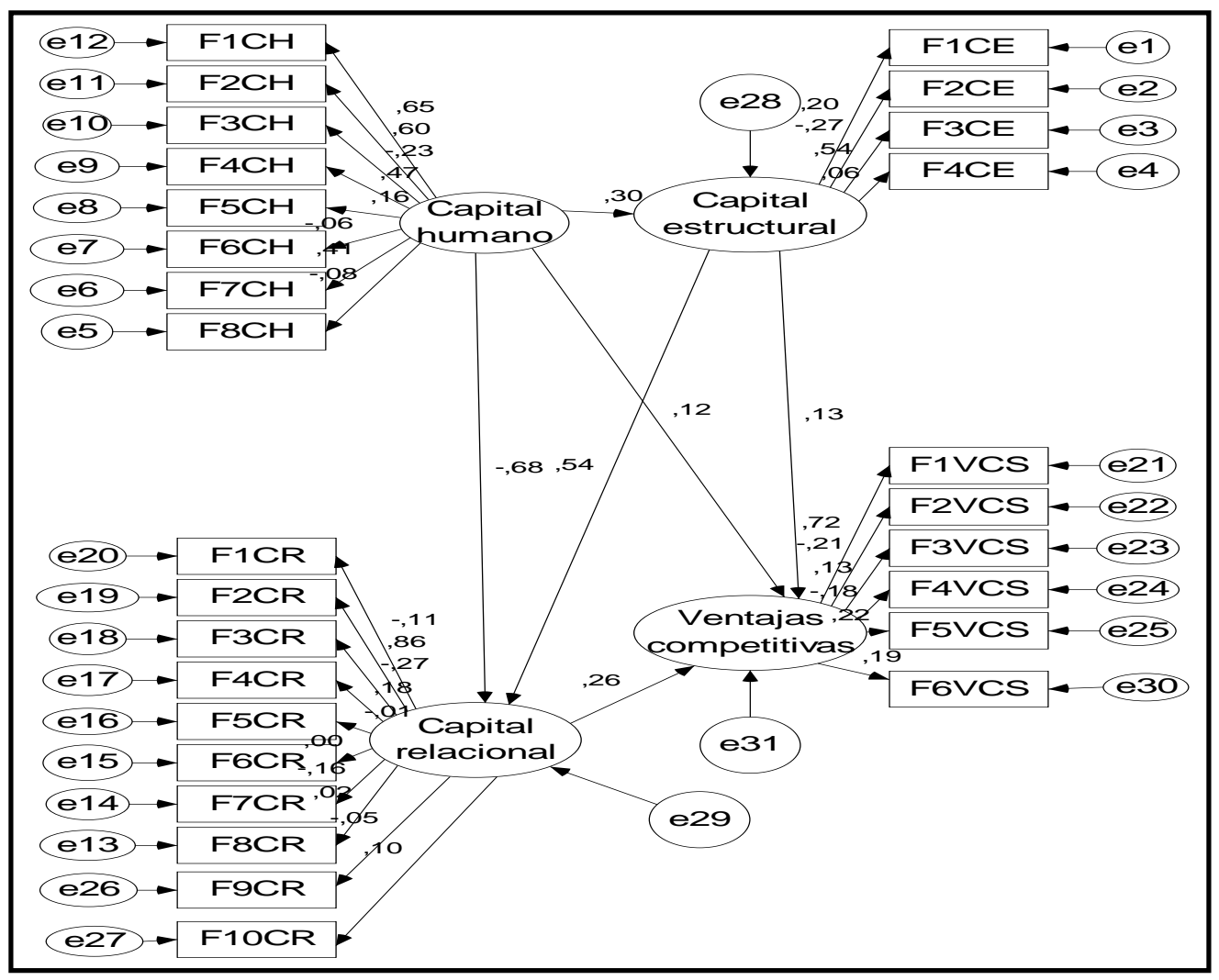

Figure 9. Model for structural equations 


\begin{tabular}{|c|c|c|c|c|c|c|}
\hline \multicolumn{7}{|c|}{ RESULTS OF THE MODEL } \\
\hline & & & Estimation & S.E. & R. C & $\mathrm{P}$ \\
\hline Structural Capital & $<--$ & Human Capital &, 024 & ,002 & 9,563 & $* * *$ \\
\hline Relational Capital & $<--$ & Human Capital &,- 332 & ,011 & $-28,897$ & $* * *$ \\
\hline Relational Capital & $<--$ & Structural Capital & 3,336 & ,147 & 22,673 & $* * *$ \\
\hline Competitive Advantages & $<--$ & Human Capital &, 041 & ,016 & 2,601 &, 009 \\
\hline Competitive Advantages & $<--$ & Relational Capital &, 184 & ,033 & 5,568 & $* * *$ \\
\hline Competitive Advantages & $<--$ & Structural Capital & ,582 &, 184 & 3,169 & ,002 \\
\hline FACTOR1CE & $<--$ & Structural Capital & 1,000 & & & \\
\hline FACTOR2CE & $<---$ & Structural Capital &,- 990 &, 117 & $-8,457$ & $* * *$ \\
\hline FACTOR3CE & $<--$ & Structural Capital & 3,155 & , 160 & 19,696 & $* * *$ \\
\hline FACTOR4CE & $<--$ & Structural Capital &, 352 & , 179 & 1,968 & ,049 \\
\hline FACTOR8CH & $<---$ & Human Capital &,- 051 & 021 & $-2,399$ & ,016 \\
\hline FACTOR7CH & $<--$ & Human Capital & ,447 & 032 & 13,812 & $* * *$ \\
\hline FACTOR6CH & $<--$ & Human Capital &,- 041 &, 023 & $-1,807$ & ,071 \\
\hline FACTOR5CH & $<---$ & Human Capital & ,118 &, 024 & 4,853 & $* * *$ \\
\hline FACTOR4CH & $<---$ & Human Capital & , 184 & ,012 & 15,941 & $* * *$ \\
\hline FACTOR3CH & $<--$ & Human Capital &,- 111 & ,015 & $-7,256$ & $* * *$ \\
\hline FACTOR2CH & $<--$ & Human Capital &, 515 &, 023 & 22,519 & $* * *$ \\
\hline FACTOR1CH & $<--$ & Human Capital & 1,000 & & & \\
\hline FACTOR8CR & $<--$ & Relational Capital & ,016 &, 022 & ,738 & 460 \\
\hline FACTOR7CR & $<---$ & Relational Capital &,- 150 &, 031 & $-4,765$ & $* * *$ \\
\hline FACTOR6CR & $<--$ & Relational Capital &,- 002 &, 034 &,- 065 & ,948 \\
\hline FACTOR5CR & $<--$ & Relational Capital &,- 007 & ,034 &,- 209 & ,834 \\
\hline FACTOR4CR & $<---$ & Relational Capital & , 100 & ,018 & 5,623 & $* * *$ \\
\hline FACTOR3CR & $<--$ & Relational Capital &,- 259 & ,030 & $-8,583$ & $* * *$ \\
\hline FACTOR2CR & $<--$ & Relational Capital & 1,000 & & & \\
\hline FACTOR1CR & $<---$ & Relational Capital &,- 099 & ,030 & $-3,354$ & $* * *$ \\
\hline FACTOR1VCS & $<--$ & Competitive Advantages & 1,000 & & & \\
\hline FACTOR2VCS & $<--$ & Competitive Advantages &,- 272 &, 041 & $-6,638$ & $* * *$ \\
\hline FACTOR3VCS & $<---$ & Competitive Advantages & , 109 &, 027 & 4,103 & $* * *$ \\
\hline FACTOR4VCS & $<--$ & Competitive Advantages &,- 256 & ,046 & $-5,531$ & $* * *$ \\
\hline FACTOR5VCS & $<--$ & Competitive Advantages &, 111 & ,016 & 6,982 & $* * *$ \\
\hline FACTOR9CR & $<--$ & Relational Capital &,- 033 & 023 & $-1,412$ &, 158 \\
\hline FACTOR10CR & $<--$ & Relational Capital & ,085 & ,028 & 3,036 & ,002 \\
\hline FACTOR6VCS & $<--$ & Competitive Advantages & 132 &, 022 & 5,889 & $* * *$ \\
\hline
\end{tabular}

\section{Figure 10. Results of the model}

We present some conclusions derived form the global adjustment of the structural equations model. 


\section{Conclusions}

The results have been contrasted with the group of experts in the group dynamics and personal interviews. We can add here that we have found a great positive influence of $\mathrm{HC}$ and SC, not being positively influenced in the RC (this could be the case that in firms with a high HC degree rivalries phenomenon may appear, conflicts of interest that make more difficult the perception of a good degree in the relationships). However the improvement of $\mathrm{HC}$ has a positive impact on the generation of SCA. The increase of SC positively impacts in the RC and in the generation of SCA. At the same time it also impacts in a positive way in the generation of SCA.

As main final conclusion and once we have checked the hypotheses, the adoption of ECR practices generates and/or increases the intellectual capital or knowledge in organisations that has a positive influence in the generation and improvement of sustainable competitive advantages.

As main restrictions to our analysis we can stress the lack of publications (books, doctoral dissertations, articles) on ECR initiatives, especially in the Spanish Market. However as a strong point for our literature review, we had the privilege of working with confidential reports, offered by a group of organisations (AECOC, PROMARCA, ECR-Spain).

In relation with the elements we have include in the model, we must point out that not all the firms are using the same practices and the same "associated concepts", although they have heard about them. In some cases, with the main objectives of have the surveys completed, we have worked under the analysis "what if".

The model of structural equations containing latent variables and errors of measure requires a high volume of data. We have solved that limitation by using the following statistical tools: factor analysis in main components and the Markov chain Monte Carlo method. We have considered a model with non reciprocal direct relationships for avoiding a very complex model and promoting a more clear interpretation of the final results.

By considering the just mentioned restrictions and the obtained conclusions, we suggest the following future research topics.

We consider of interest extrapolating the model to other industries. This will allow us to establish comparison of the effectiveness achieved by using ECR practices in different industries.

We also consider of interest deepening the study of most frequent ECR practices, according to the industry and their impact on the firm's intellectual capital and sustainable competitive advantages.

The identification of new indicators and their convenience for being included in the different parts of the proposed model should be also of interest for future research.

Another interesting derived analysis could be the consideration of the temporal dimension in the model, since the degree of implementation of these practices takes place in the long run.

Finally, we also consider of interest to study the ECR initiatives from the point of view of the existence literature concerning to collaboration and alliance agreements in other environments. Since the ECR initiatives include amongst their main elements the so-called co-operation strategies, apart from other enabling tools and a group of associated concepts that even not being intrinsic to ECR practices, are however considered of a great interest.

\section{References}

AECOC. (2000). A system for measuring the evolution of management indexes. AECOC, Barcelona.

AECOC. (2005). Annual Report 2005. Aecoc, Barcelona. 
AECOC; ECR-España; Accenture (2002). Project on ECR indexes, year 2002 edition. Report, Barcelona.

Amponsem, H. (1991). Organizational learning through internal systems, strategic alliances and networks. Doctoral Dissertation, Queen's University at Kingston, Canadá.

Andreu, R., Ricart, J. E., \& Valor, J. (1997). The organization on the information age. Madrid: McGrawHill.

Brooking, A. (1996). Intellectual capital: Core assets for the third millennium enterprise. Londres: Thomson Business Press.

Buddenbaum, S. (1994). A tribute to a great Nabisco Foods Team. Opinion on the Joe's Corner Blog, in http://www.vics.org/blog

Bueno, E., Rodríguez, O., \& Salmador, M. P. (2003). The importance of social capital in the knowledge society: the proposal of an intellectual capital integrated model. I International Conference in Virtual and Intangibles.

Ciborra, C. U. \& Andreu, R. (2001). Sharing knowledge across boundaries. Journal of Information Technology, 16, 73-81.

ECR -Spain. (1998). Continuos Replenishment (CRP). Report.

Ferrer, J., \& del Castillo, G. (1996). ECR, first actions in Spain. Código 84 Review, 54(May/June).

Gil, I., \& Guarch, J. J. (2006). PE - IT/IS Strategic planning. Retrieved from www.personales.upv.es/igil/lio.pdf

Jöreskog, K. G. (1993). Modelling structural equations. Guipúzcoa: Euskadiko

Kurt Salmon Associates, Inc. (1993). Efficient consumer response: Enhancing consumer value in the grocery industry. Washington, DC: Food Marketing Institute.

Mejías, A., García, J., \& Prado, J. C. (2001). Technology and best practices as enabling elements for the management of the supply chain, XI Congreso Nacional de ACEDE, Zaragoza.

Merrefield, D. (1992, October 5). Big -A Powers Growth at Daiei. Supermarket News, pp. 11-15

Nonaka, I. (1995). The knowledge-creating company: How Japanese companies create the dynamics for innovation. New York: Oxford University Press.

Ordóñez, P. (2000). Strategic tools for measuring the organizational intellectual capital. Revista de Estudios Empresariales, $\mathrm{n}^{\circ}$ 102, Junio, Universidad de Deusto, pp. 36-42.

Palou, C. (2006). Personalised solutions: an integral response to all business needs. $1^{\circ}$ taller nacional de tecnologías aplicadas al sector hotelero: 20 casos de éxito, 20 soluciones reales. Informática El Corte Inglés, en www.fundetec.es

PROMARCA, Asociación Española de Productos de Marca (2000), Annual Report, Internal working paper.

Rambla, D. (2006). ITSGA: Standard actions to achieve sustainable competitive advantages. Available at www.danielrambla.com

Shulman, R. (1993). Will the ECR report evoke effective corporate responses? Supermarket Business, 48, 21

Shulman, R. (2001). Perishable systems take center stage. Supermarket Business, 56(4), 47-48.

Solé, M. L. (2000). Comercio electrónico: un mercado en expansión. ESIC Editorial, Madrid.

Soret, I. (2007). A model to measure the creation of knowledge and sustainable competitive advantages coming from the Efficient Consumer Response initiative. Doctoral Dissertation.

Soto, J. L., \& Tapia, D. (2006). IS/IT Strategic planning. Available at www.bibliotecnica.upc.es 
Stern, L., El-Ansary, A., Curghlan, A., \& Cruz, I. (1999). Marketing channels (5th ed.). Madrid: Prentice Hall.

Veiders, Ch. (1993). Panel sees unique ECR challenges. Food Marketing Institute Conference. Supermarket news.

Whipple, J., Frankel, R., \& Anselmi, K. (1999). The effect of governance structure on performance: A case study of efficient consumer response. Journal of Business Logistics, 20(2), 43-62.

\section{Appendix \\ List of Variables or Indexes}

\begin{tabular}{|c|c|c|}
\hline \multicolumn{3}{|c|}{ VISTA DE VARIABLES } \\
\hline \multicolumn{3}{|c|}{ BLOQUE I } \\
\hline 1 & I.1 & Increase of success IDEAS \\
\hline 2 & I.2.a & Improvement of the ATTITUDE for people participation \\
\hline 3 & $1.2 . \mathrm{b}$ & Improvement of the BEHAVIOUR for people participation \\
\hline 4 & 1.2.c & Improvement of the SKILLS for people participation \\
\hline 5 & 1.3 & Increase of multitask capacity \\
\hline 6 & 1.4 & Increase of task rotation \\
\hline 7 & $1.5 . \mathrm{a}$ & Increase of loyalty and compromise \\
\hline 8 & $1.5 . \mathrm{b}$ & Increase of royalty and involvement \\
\hline 9 & $1.5 . \mathrm{c}$ & Increase of royalty and transformation \\
\hline 10 & $1.6 . \mathrm{a}$ & Increase of training programmes in associate concepts (BPR) \\
\hline 11 & $1.6 . \mathrm{b}$ & Increase of training programmes in associate concepts (ABC) \\
\hline 12 & $1.6 . c$ & Increase of training programmes in associate concepts (TQM) \\
\hline 13 & 1.6.d & Increase of training programmes in associate concepts (KAIZEN) \\
\hline 14 & 1.6.e & Increase of training programmes in associate concepts (MRP/DRP) \\
\hline 15 & 1.6.f & Increase of training programmes in associate concepts (CIM) \\
\hline 16 & 1.6.g & Increase of training programmes in associate concepts (TRADE MK) \\
\hline 17 & 1.6.h & Increase of training programmes in associate concepts $(\mathrm{BENCH})$ \\
\hline 18 & 1.6.i & Increase of training programmes in associate concepts (JIT) \\
\hline 19 & 1.6.j & Increase of training programmes in associate concepts (ISI) \\
\hline 20 & $1.6 . \mathrm{k}$ & Increase of training programmes in associate concepts (IT) \\
\hline 21 & 1.6 .1 & Increase of training programmes in associate concepts (OUTSOURCING) \\
\hline 22 & $1.6 . \mathrm{m}$ & Increase of training programmes in associate concepts (PARTNER) \\
\hline 23 & $1.6 . \mathrm{n}$ & Increase of training programmes in associate concepts (CONCURRENT ENGINEERING) \\
\hline 24 & 1.6 .0 & Increase of training programmes in associate concepts (ILS) \\
\hline 25 & 1.7.a & Improvement in the labour individual climate (employment security and future) \\
\hline 26 & $1.7 . \mathrm{b}$ & Improvement in the labour individual climate (work conditions) \\
\hline 27 & $1.7 . \mathrm{c}$ & Improvement in the labour individual climate (work environment) \\
\hline 28 & 1.7.d & Improvement in the labour individual climate (rewards) \\
\hline 29 & 1.7.e & Improvement in the labour individual climate (Education-training) \\
\hline 30 & 1.7.f & Improvement in the labour individual climate (Information and communication) \\
\hline 31 & $1.7 . \mathrm{g}$ & Improvement in the labour individual climate (Management by objectives) \\
\hline 32 & 1.7.h & Improvement in the labour individual climate (work participation) \\
\hline 33 & 1.7.i & Improvement in the labour individual climate (managerial style) \\
\hline 34 & 1.7.j & Improvement in the labour individual climate (Promotion) \\
\hline 35 & $1.7 . \mathrm{k}$ & Improvement in the labour individual climate (firm integration ) \\
\hline 36 & $1.8 . \mathrm{a}$ & Improvement in the labour group climate (employment security and future) \\
\hline 37 & $1.8 . \mathrm{b}$ & Improvement in the labour group climate (work conditions) \\
\hline
\end{tabular}




\section{Efficient Consumer Response}

\begin{tabular}{|c|c|c|}
\hline 38 & $1.8 . \mathrm{c}$ & Improvement in the labour group climate (work environment) \\
\hline 39 & 1.8.d & Improvement in the labour group climate (rewards) \\
\hline 40 & 1.8.e & Improvement in the labour group climate (Education-training) \\
\hline 41 & 1.8.f & Improvement in the labour group climate (Information and communication) \\
\hline 42 & $1.8 . \mathrm{g}$ & Improvement in the labour group climate (Management by objectives) \\
\hline 43 & 1.8.h & Improvement in the labour group climate (work participation) \\
\hline 44 & $1.8 . \mathrm{i}$ & Improvement in the labour group climate (managerial style) \\
\hline 45 & 1.8.j & Improvement in the labour group climate (Promotion) \\
\hline 46 & 1.8.k & Improvement in the labour group climate (firm integration ) \\
\hline 47 & 1.9.a & Improvement in learning (physical space) \\
\hline 48 & 1.9.b & Improvement in learning (virtual space) \\
\hline 49 & 1.9.c & Improvement in learning (communities of practice) \\
\hline 50 & 1.9.d & Improvement in learning (Peer assist techniques) \\
\hline 51 & 1.9.e & Improvement in learning (war rooms) \\
\hline 52 & 1.9.f & Improvement in learning (lessons learned ) \\
\hline 53 & $1.9 . \mathrm{g}$ & Improvement in learning (virtual community) \\
\hline 54 & 1.9.h & Improvement in learning (virtual university) \\
\hline 55 & 1.9.i & Improvement in learning (individual initiative) \\
\hline \multicolumn{3}{|c|}{ BLOQUE II } \\
\hline 56 & II.10.a & Improvement in the customer systems (DATA WAREHOUSE) \\
\hline 57 & II.10.b & Improvement in the customer systems (DATA MINING) \\
\hline 58 & II.10.c & Improvement in the customer systems (CRM) \\
\hline 59 & II.11.a & Improvement in the organisation systems (EDI) \\
\hline 60 & II.11.b & Improvement in the organisation systems (XML) \\
\hline 61 & II.11.c & Improvement in the organisation systems (INTERNET/EXTRANET) \\
\hline 62 & II.12 & Improvement in the organisation systems (Improvement and/or creation of procedures manuals) \\
\hline 63 & II.13 & Improvement and / or adoption of best practices \\
\hline 64 & II.14 & Improvement in processes efficiency \\
\hline 65 & II.15 & Improvement in the equipments \\
\hline 66 & II.16.a & Efficiency in the corporate university ( physical space) \\
\hline 67 & II.16.b & Efficiency in the corporate university (virtual spaces) \\
\hline 68 & II.16.c & Efficiency in the corporate university (Communities of practice) \\
\hline 69 & II.16.d & Efficiency in the corporate university (Peer assist techniques) \\
\hline 70 & II.16.e & Efficiency in the corporate university (war frameworks) \\
\hline 71 & II.16.f & Efficiency in the corporate university (Lessons learned) \\
\hline 72 & II.16.g & Efficiency in the corporate university (virtual communities) \\
\hline 73 & II.16.h & Efficiency in the corporate university (virtual university) \\
\hline 74 & II.17 & Efficiency in the corporate university (improve in marketing new products) \\
\hline \multicolumn{3}{|c|}{ BLOQUE III } \\
\hline 75 & III.18.a & Organisational knowledge and influence in customers (customers DBMS) \\
\hline 76 & III.18.b & Organisational knowledge and influence in customers (knowing of new customers) \\
\hline 77 & III.18.c & Organisational knowledge and influence in customers (Profile identification) \\
\hline 78 & III.18.d & Organisational knowledge and influence in customers (loyalty programmes) \\
\hline 79 & III.18.e & Organisational knowledge and influence in customers (up-selling programmes) \\
\hline 80 & III.18.f & Organisational knowledge and influence in customers (cross-selling programmes) \\
\hline 81 & III.19.a & CUSTOMER SATISFACTION (satisfaction programmes ) \\
\hline 82 & III.19.b & CUSTOMER SATISFACTION (identification of standards programmes) \\
\hline 83 & III.19.c & CUSTOMER SATISFACTION (service improvement programmes) \\
\hline 84 & III.20.a & Collaboration agreements (AFM) \\
\hline
\end{tabular}




\begin{tabular}{|c|c|c|}
\hline 85 & III.20.b & Collaboration agreements (OER) \\
\hline 86 & III.20.c & Collaboration agreements (CRP) \\
\hline 87 & III.20.d & Collaboration agreements (CPFR) \\
\hline 88 & III.20.e & Collaboration agreements (ASN) \\
\hline 89 & III.20.f & Collaboration agreements (CATEGORY MANAGEMENT) \\
\hline 90 & III.20.g & Collaboration agreements (MULTICOLLECTION) \\
\hline 91 & III.20.h & Collaboration agreements (CROSS-DOCKING) \\
\hline 92 & III.21.a & Participation in practices ECR (AFM) \\
\hline 93 & III.21.b & Participation in practices ECR (OER) \\
\hline 94 & III.21.c & Participation in practices ECR (CRP) \\
\hline 95 & III.21.d & Participation in practices ECR (CPFR) \\
\hline 96 & III.21.e & Participation in practices ECR (ASN) \\
\hline 97 & III.21.f & Participation in practices ECR (CATEGORY MANAGEMENT) \\
\hline 98 & III.21.g & Participation in practices ECR (MULTICOLLECTION) \\
\hline 99 & III.21.h & Participation in practices ECR (CROSS-DOCKING) \\
\hline 100 & III.22.a & STAKEHOLDERS satisfaction (Providers) \\
\hline 101 & III.22.b & STAKEHOLDERS satisfaction (Customers) \\
\hline 102 & III.22.c & STAKEHOLDERS satisfaction(Stakeholders) \\
\hline 103 & III.22.d & STAKEHOLDERS satisfaction (Society/Public Opinion) \\
\hline 104 & III.23.a & Increase in the use of EPI (To consummers) \\
\hline 105 & III.23.b & Increase in the use of EPI (To providers) \\
\hline 106 & III.23.c & Increase in the use of EPI (To selling points) \\
\hline 107 & III.24.a & EPI customer satisfaction (Consummers) \\
\hline 108 & III.24.b & EPI customer satisfaction (Providers) \\
\hline 109 & III.24.c & EPI customer satisfaction (Selling points) \\
\hline 110 & III.25.a & Efficiency of CRM-Cooperative (General) \\
\hline 111 & III.25.b & Efficiency of CRM-Cooperative (SFA) \\
\hline 112 & III.26.a & B2B practices effciciency \\
\hline 113 & III.26.b & B2C practices efficiency \\
\hline \multicolumn{3}{|c|}{ BLOQUE IV } \\
\hline 114 & IV.27.a & Importance of the product information to SC (in design) \\
\hline 115 & IV.27.b & Importance of the product information to SC (in innovation) \\
\hline 116 & IV.27.c & Importance of the product information to SC (in new products) \\
\hline 117 & IV.28.a & Importance of the product information to Consumer (in design) \\
\hline 118 & IV.28.b & Importance of the product information to Consumer (in innovation) \\
\hline 119 & IV.28.c & Importance of the product information to Consumer (in new products) \\
\hline 120 & IV.29.a & Difference between the information on product offered and expected to SC (in design) \\
\hline 121 & IV.29.b & Difference between the information on product offered and expected to SC (in innovation) \\
\hline 122 & IV.29.c & Difference between the information on product offered and expected to SC (in new products) \\
\hline 123 & IV.30.a & Difference between the information on product offered and expected to consumer (in design) \\
\hline 124 & IV.30.b & Difference between the information on product offered and expected to consumer (in innovation) \\
\hline 125 & IV.30.c & Difference between the information on product offered and expected to consumer (in new products) \\
\hline 126 & IV.31.a & Improve of the product information to SC (in design) \\
\hline 127 & IV.31.b & Improve of the product information to SC (in innovation) \\
\hline 128 & IV.31.c & Improve of the product information to SC (in new products) \\
\hline 129 & IV.32.a & Improve of the product information to consumer (in design) \\
\hline 130 & IV.32.b & Improve of the product information to consumer (in innovation) \\
\hline 131 & IV.32.c & Improve of the product information to consumer (in new products) \\
\hline 132 & IV.33.a & Improvement of the PERSONALISATION OF PRODUCT OR SERVICE (TO PROVIDERS) \\
\hline
\end{tabular}




\begin{tabular}{|c|c|c|}
\hline 133 & IV.33.b & Improvement of the PERSONALISATION OF PRODUCT OR SERVICE (TO CUSTOMERS) \\
\hline \multicolumn{3}{|c|}{ BLOQUE V } \\
\hline 134 & V.34.a & Improve for CUSTOMERS (Price) \\
\hline 135 & V.34.b & Improve for CUSTOMERS (Portfolio) \\
\hline 136 & V.34.c & Improve for CUSTOMERS (Promotions) \\
\hline 137 & V.34.d & Improve for CUSTOMERS (EPI) \\
\hline \multicolumn{3}{|c|}{ BLOQUE VI } \\
\hline 138 & VI.35 & COMPETITIVE ADVANTAGES in DISTRIBUTION by EFFICIENT AGREEMENTS \\
\hline 139 & VI.36 & COMPETITIVE ADVANTAGES in DISTRIBUTION by COMMUNICATION AGREEMENTS \\
\hline \multicolumn{3}{|c|}{ BLOQUE VII } \\
\hline 140 & VII.37.a & COMPETITIVE ADVANTAGES in PROVIDERS by ECR practices (AFM) \\
\hline 141 & VII.37.b & COMPETITIVE ADVANTAGES in PROVIDERS by ECR practices (OER) \\
\hline 142 & VII.37.c & COMPETITIVE ADVANTAGES in PROVIDERS by ECR practices (CRP) \\
\hline 143 & VII.37.d & COMPETITIVE ADVANTAGES in PROVIDERS by ECR practices (CPFR) \\
\hline 144 & VII.37.e & COMPETITIVE ADVANTAGES in PROVIDERS by ECR practices (ASN) \\
\hline 145 & VII.37.f & COMPETITIVE ADVANTAGES in PROVIDERS by ECR practices (GESTIÓN POR CATEGORÍAS) \\
\hline \multicolumn{3}{|c|}{ BLOQUE VIII } \\
\hline 146 & VIII.38 & Interest in promoting an ELECTRONIC MARKET \\
\hline 147 & VIII.39 & Some other ECRSGA? \\
\hline \multicolumn{3}{|c|}{ BLOQUE IX } \\
\hline 148 & IX.40.a & Conceptos asociados como FACILITADORES ECR (BPR) \\
\hline 149 & IX.40.b & Conceptos asociados como FACILITADORES ECR (ABC) \\
\hline 150 & IX.40.c & Conceptos asociados como FACILITADORES ECR (TQM) \\
\hline 151 & IX.40.d & Conceptos asociados como FACILITADORES ECR (KAIZEN) \\
\hline 152 & IX.40.e & Conceptos asociados como FACILITADORES ECR (MRP) \\
\hline 153 & IX.40.f & Conceptos asociados como FACILITADORES ECR (DRP) \\
\hline 154 & IX.40.g & Conceptos asociados como FACILITADORES ECR (JIT) \\
\hline 155 & IX.40.h & Conceptos asociados como FACILITADORES ECR (TRADE MK) \\
\hline 156 & IX.40.i & Conceptos asociados como FACILITADORES ECR (BENCH) \\
\hline 157 & IX.40.j & Conceptos asociados como FACILITADORES ECR (SISTEMAS DE INFORMACIÓN) \\
\hline 158 & IX.40.k & Conceptos asociados como FACILITADORES ECR (NUEVAS TECNOLOGÍAS) \\
\hline 159 & IX.40.1 & Conceptos asociados como FACILITADORES ECR (OUTSOURCING) \\
\hline 160 & IX.40.m & Conceptos asociados como FACILITADORES ECR (PARTNERSHIP SOURCING) \\
\hline 161 & IX.40.n & Conceptos asociados como FACILITADORES ECR (INGENIERÍA CONCURRENTE) \\
\hline 162 & IX.40.o & Conceptos asociados como FACILITADORES ECR (ILS) \\
\hline 163 & IX.41.a & ECR CRITICAL SUCCESS FACTORS (Managerial Compromise) \\
\hline 164 & IX.41.b & ECR CRITICAL SUCCESS FACTORS (Leadership) \\
\hline 165 & IX.41.c & ECR CRITICAL SUCCESS FACTORS (Multi task team) \\
\hline 166 & IX.41.d & ECR CRITICAL SUCCESS FACTORS (Critical mass needed) \\
\hline 167 & IX.41.e & ECR CRITICAL SUCCESS FACTORS (participant's compromise) \\
\hline 168 & IX.41.f & ECR CRITICAL SUCCESS FACTORS (information and communication systems) \\
\hline 169 & IX.41.g & ECR CRITICAL SUCCESS FACTORS (New technologies) \\
\hline 170 & IX.41.h & ECR CRITICAL SUCCESS FACTORS (Individual learning capacity) \\
\hline 171 & IX.41.i & ECR CRITICAL SUCCESS FACTORS (Collective learning capacity) \\
\hline 172 & IX.41.j & ECR CRITICAL SUCCESS FACTORS (Organisational capacity with process orientation) \\
\hline 173 & IX.41.k & ECR CRITICAL SUCCESS FACTORS (Training programs) \\
\hline 174 & IX.41.1 & ECR CRITICAL SUCCESS FACTORS (Actions for improvement) \\
\hline 175 & IX.41.m & ECR CRITICAL SUCCESS FACTORS (Labour climate) \\
\hline 176 & IX.41.n & ECR CRITICAL SUCCESS FACTORS (personal initiative) \\
\hline
\end{tabular}




\section{Biographies}

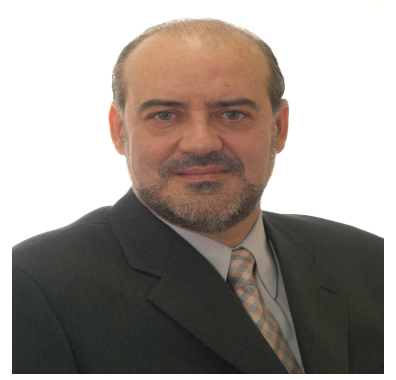

Ignacio Soret is a Lecturer for graduates and pos-graduates in the areas of production, logistics and supply chain at the Marketing \& Business School, ESIC (Rey Juan Carlos University), Spain, since 1992. He has got a Degree in Telecommunication Engineering and has a PHD in Business Administration. He is author of specialised books and has Publisher in specialised reviews.

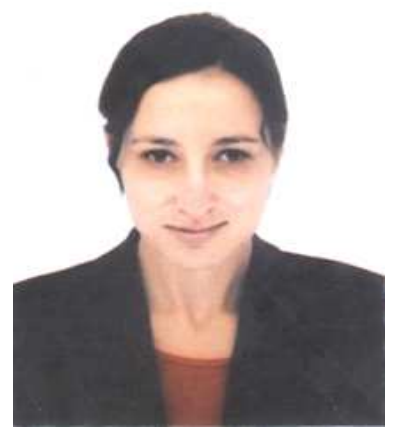

Carmen de Pablos is a Professor in the Business Administration Area at the Rey Juan Carlos University in Madrid, Spain from 1994. She is specialised in the impact of information technologies over organisational systems and entrepreneurship where she develops main research. She has presented communications in different international venues and has published in specialised journals. She has also worked as a consultant in the area of IS management at Primma Consulting.

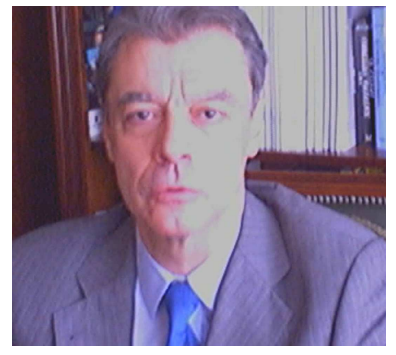

Jose Luis Montes is a Professor at the Rey Juan Carlos University. He has published articles and developed models of simulation in Social Sciences. He is a specialist in analysis multivariate and systems of structural equations with latent variables. 